\section{Metastaser ved thyreoideakarsinom}

Mange av dem som blir operert for papillært thyreoideakarsinom har subklinisk lymfeknutesykdom ved operasjonstidspunktet, noe som er assosiert med økt fare for tilbakefall (Ann Surg 2009; 250: 403-8). Profylaktisk bilateral fjerning av lymfeknuter sentralt på halsen kan medføre komplikasjoner, og i en amerikansk studie undersøkte man sikkerheten ved ipsilateral fjerning.

Hos 45 av pasientene ble disseksjonen delt i høyre og venstre side før patologisk undersøkelse. $53 \%$ hadde lymfeknutemetastaser. Ingen av dem med tumor $\leq 1 \mathrm{~cm}$ hadde bilaterale positive lymfeknuter, mot $31 \%$ av dem med tumor $>1 \mathrm{~cm}$. Ipsilateral lymfeknutefjerning synes å være tilstrekkelig ved tumorstørrelse $\leq 1 \mathrm{~cm}$.

\section{Parenteral fiskeolje ved kolestase}

Leverskade etter parenteral ernæring kan være en dødelig komplikasjon hos barn med kort tarm-syndrom. I en amerikansk studie undersøkte man sikkerheten ved bruk av intravenøs lipidoppløsning med fiskeolje hos 42 barn som hadde utviklet kolestase (s-bilirubin $\geq 2 \mathrm{mg} / 100 \mathrm{ml}$ ) mens de fikk lipidoppløsning med soyaolje parenteralt (Ann Surg 2009; 250: 395-402).

Denne gruppen ble sammenliknet med en gruppe på 49 spedbarn med kort tarmsyndrom og kolestase hvis parenterale ernæring kun besto av soyaolje. I fiskeoljekohorten var det tre dødsfall og en levertransplantasjon, mot 12 dødsfall og seks transplantasjoner $\mathrm{i}$ soyaoljekohorten $(p=0,005)$.

\section{Famotidin forebygger magesår}

Famotidin, en $\mathrm{H}_{2}$-reseptorantagonist, forebygger magesår og øsofagitt hos pasienter som tar lave doser acetylsalisylsyre (75-325 mg), ifølge en fase 3-studie publisert i The Lancet (2009; 374: 119-25).

400 voksne som tok acetylsalisylsyre hver dag ble randomisert til å få famotidin $20 \mathrm{mg}$ eller placebo to ganger daglig. Etter 12 uker ble alle undersøkt endoskopisk.

Forskerne fant magesår hos $3 \%$ av dem som fikk famotidin og hos $15 \%$ i placebogruppen. Det var også lavere forekomst av duodenalsår, erosiv øsofagitt og bivirkninger i famotidingruppen.

\title{
Alternativ til warfarin ved atrieflimmer
}

\section{Trombinhemmeren dabigatran er enklere i bruk enn warfarin og fore- bygger sannsynligvis hjerneslag like effektivt.}

For å forebygge hjerneslag skal pasienter med atrieflimmer helst bruke antikoagulerende medikamenter. K-vitaminantagonisten warfarin medfører betydelig blødningsrisiko og er komplisert å bruke fordi det er nødvendig med stadige kontroller av koaguleringstiden (INR). Dabigatran er en trombinhemmer som kan tas peroralt. Dette medikamentet er foreløpig godkjent som alternativ til heparin for å hindre postoperativ trombose.

Resultatene av en klinisk studie med over 18000 pasienter viser at dabigatran kanskje kan erstatte vitamin K-antagonister hos pasienter med atrieflimmer (1). Pasientene ble delt i tre grupper: to som fikk enten 110 $\mathrm{mg}$ eller $150 \mathrm{mg}$ dabigatran daglig (blindet) og én som fikk warfarin justert etter INRnivå (ikke blindet). I løpet av to år var forekomsten av hjerneslag signifikant lavere i gruppen som fikk den høyeste dosen dabigatran, mens den laveste dosen ga omtrent samme risiko som warfarin. Hos dem som fikk $150 \mathrm{mg}$ dabigatran var forekomsten av alvorlige blødninger omtrent den samme som forekomsten i warfaringruppen. Forskjellen mellom gruppene når det gjaldt dødelighet var grensesignifikant, med litt høyere overlevelse i gruppen som fikk $150 \mathrm{mg}$ dabigatran daglig.

- Dette er oppmuntrende resultater, sier professor Åsmund Reikvam ved Institutt for farmakoterapi, Universitetet i Oslo. - Man har lenge forsøkt å utvikle perorale koagulasjonshemmere som er enklere i bruk enn warfarin. Samtidig skal slike medikamenter ha like god effekt som dem man bruker i dag og akseptabel blødningsrisiko og bivirkningsprofil. Dabigatran synes å oppfylle disse betingelsene. Andre perorale koagulasjonshemmere, særlig faktor X-hemmere, er under utprøvning i kliniske fors $\varnothing \mathrm{k}$. Nye koagulasjonshemmere kan bli aktuelle ved alle tilstander hvor vi i dag bruker warfarin.

\section{Ragnhild Ørstavik}

ragnhild.orstavik@fhi.no

Tidsskriftet

\section{Litteratur}

1. Connolly SJ, Ezekowitz MD, Yusuf S et al. Dabigatran versus warfarin in patients with atrial fibrillation. N Engl J Med 2009; 361: 1139-51.

\section{Å dø av demens}

Hvordan behandles demenspasienter, og hva dør de av? Resultatene av en stor og grundig oppfølgingsundersøkelse er nylig publisert i The New England Journal of Medicine.

Undersøkelsen inkluderte 323 sykehjemspasienter fra Boston-området med alvorlig demens (1). Alle var så demente at de ikke kjente sine nære pårørende og var helt avhengig av hjelp. Gjennomsnittsalderen var 85 år, og bare $15 \%$ var menn.

Mer enn halvparten av deltakerne døde i løpet av den 18 måneder lange oppfølgingstiden. I samme periode var forekomsten av både pneumoni, feber og spiseproblemer omkring $50 \%$ for hver av disse. Dette var også de hyppigste dødsårsakene. Bare noen få døde av hjerteinfarkt, hjerneslag eller andre plutselige hendelser. Man beskriver også forekomsten av belastende intervensjoner - for eksempel fikk $30 \%$ av dem som døde parenteral behandling i løpet av sine siste tre måneder.

- Dette er en interessant artikkel, og det ligger godt til rette for å gjøre liknende forskning i Norge, sier forskningsleder Geir
Selbæk ved Alderpsykiatrisk kompetansesenter, Sykehuset Innlandet. - Upubliserte resultater fra en norsk studie med nokså tilsvarende utvalg viste at dødeligheten hos de sykeste demenspasientene var på omkring $40 \%$ i løpet av ett år.

Det er imidlertid to viktige forhold jeg savner i artikkelen, sier Selbæk. - Det første gjelder agitasjon og psykiatriske symptomer. Forekomsten av disse øker med demensprogredieringen, og det er vist at dette er av avgjørende betydning for pasientens velvære og belastningen for pårørende og pleiepersonell. Det andre er medikamentbruken, særlig psykofarmaka, som i hvert fall i Norge brukes mye. Antakelig påvirker også slike medikamenter forløpet av demenstilstanden i sluttfasen.

\section{Ragnhild Ørstavik}

ragnhild.orstavik@fhi.no

Tidsskriftet

\section{Litteratur}

1. Mitchell SL, Teno JM, Kiely DK et al. The clinical course of advanced dementia. N Engl J Med 2009; 361: 1529-38. 